\title{
Metallogeny of lithium through geological time
}

\author{
A. V. Tkachev ${ }^{1}$, D. V. Rundqvist ${ }^{1}$, and N. A. Vishnevskaya ${ }^{1}$ \\ Received 24 May 2018; accepted 18 June 2018; published 13 November 2018.
}

The intensity of lithium accumulation through geological time has been analyzed.

For this purpose we used the data on mineral deposits which have already exploited or potentially are of economic interest and which contain at least $0.1 \times 10^{6}$ tons of $\mathrm{Li}_{2} \mathrm{O}$. Their formation was pronounced discrete and took place at various geological epochs from the Later Mesoarchean to Holocene. Each known supercontinent cycle differs in one way or another in the metallogeny of lithium. In the earliest cycles, Kenoran, Columbian, and Rodinian, exclusively pegmatite lithium deposits were generated. Moreover, this type is the only through one over the geological history, because such objects are also known in the Pangean and Amasian cycles. However, both the maximal number of such pegmatites and highest lithium grades are known for the oldest Kenoran cycle. This allows us to suppose that the Archean conditions were particularly favorable for lithium-bearing pegmatites. The lithium potential of the Pangean cycle also is mainly formed by pegmatites, except small part of resources related to lithium-fluorine ( $\mathrm{Li}-\mathrm{F}$ ) rare-metal granites. The current Amasian cycle is far from the finish and the most diverse in types of lithium deposits. Pegmatites and Li-F granites in total contain only a tenth of the cycle's resources. Known in the Miocene-Quaternary only, the epithermal stratabound deposits and especially lithium-bearing brines in salars play a main role in the cycle. In spite of the lowest lithium contents, exactly the last type gives the maximal part in total resources, as well in lithium extraction, due to the relative simplicity and efficiency of used extraction technologies. KEYWORDS: Metallogeny; lithium deposits; geological history; supercontinent cycle.

Citation: Tkachev, A. V., D. V. Rundqvist, and N. A. Vishnevskaya (2018), Metallogeny of lithium through geological time, Russ. J. Earth. Sci., 18, ES6002, doi:10.2205/2018ES000635.

\section{Introduction}

Lithium is an extremely important feedstock for innovation-driven economy. Lithium consumption has strongly increased over the last decades due to a snowballing production rise of lithium-ion batteries for cellphones, smartphones, tablets, laptops and other electronic devices for domestic, aerospace,

\footnotetext{
${ }^{1}$ Vernadsky State Geological Museum RAS, Moscow, Russia

Copyright 2018 by the Geophysical Center RAS. http://rjes.wdcb.ru/doi/2018ES000635-res.html
}

military and medical usage. The batteries are also important for electric and hybrid automobiles, grid storage of photovoltaic cells and wind turbines. Besides, lithium is widely used to produce particular sorts of glass, ceramics and glass ceramics, industrial greases, plastics and tire rubber. It is broadly used in smelting of steel, aluminum, and light aircraft alloys, in production of cooling, drying and air cleaning systems, in fabrication of drugs and some other goods [Christmann et al., 2015.

The accelerating use of lithium led to the increase of its annual extraction from mines worldwide: in 2017 it reached 0.1 million tons 
in terms of $\mathrm{Li}_{2} \mathrm{O}$ (Jaskula, 2018), Lithium, U.S. Geological Survey, Mineral Commodity Summaries, https://minerals.usgs.gov/minerals/ pubs/commodity/lithium/mcs-2018-lithi.pdf access April 10, 2018) which is roughly three times as much as at the turn of the 20-21st century (Ober, January 2001), https://minerals.usgs.gov/minerals /pubs/commodity/lithium/450301.pdf, access April 10, 2018) The geological prospecting companies in different countries all over the world have demonstrated strong interest in this element and have initiated active exploration projects at formerly known lithium occurrences, as well as at the newly identified ones.

This trend is also reflected in the growth of the number of scientific publications in the field of geology, economic geology and ore technology, considering lithium as a subject matter at different levels - from an individual deposit to the global analysis [Christmann et al., 2015, Evans, 2014, Kesler et al., 2012, Li et al., 2015, Linde et al., 2000; and references therein]. Numerous recent studies address such issues as the type, age and location of the most important world mineral deposits. At the same time, none of those publications have provided a clear picture of geohistorical tendencies for economically viable lithium accumulations in the Earth crust or the relative role of each deposit type in different geological epochs. The recently presented distribution diagram of pegmatite-related lithium resources on the geological timescale $[\mathrm{Mc}$ Cauley and Bradley, 2014 can be considered as the first maiden attempt in this field. However, it was based on the limited sampling [Kesler et al., 2012 that has partly lost its relevance today. Moreover, McCauley and Bradley segmented the timescale of the diagram into large 100-m.y. bins and provided just a limited analysis of the metallogenic trends following from it. To the best of our knowledge, the attempts to perform similar analysis for other types of lithium deposits have never been undertaken.

In this paper we aim to fill in the existing gaps in the geohistorical record of the lithium metallogeny using the most up-to-date information available on the topic.

Here we focus on the lithium deposits belonging only to the types that have already been exploited or are being actively developed to be exploited soon. These types are: a) granite pegmatite, b) lithium-fluorine (Li-F) rare-metal granite, c) epithermal stratabound deposits, and d) brines of dry or seasonally drying salt lakes - salars [Christmann et al., 2015, Evans, 2014, Kesler et al., 2012, Linde et al., 2000.

Geothermal waters, circulating in the geodynamically active regions with lithium-bearing salars, were claimed to be promising lithium resources in some research works. [Christmann et al., 2015. Evans, 2014; Kesler et al., 2012; and references therein]. The underground waters of oil fields are also on the list of the perspective lithium feedstocks [Christmann et al., 2015, Linde et al., 2000. The geothermal and oil fields waters are very similar to the salar brines in terms of phase-chemical composition but have lower lithium grades. However, the results of experimental works at such objects have been estimated as questionable in terms of possible commercial success of lithium mining [Christmann et al., 2015. Hence, we excluded them from our survey.

\section{Analyzed Data and Methodology}

The study is directly based on the database "Large and Superlarge Mineral Deposits of the World", generated and constantly updated by Vernadsky State Geological Museum, RAS [Rundqvist et al., 2004, 2006. The database is publicly available in Russian and English as a WEB-GIS-version on the Internet [Tkachev et al., 2015. The analyzed mineral deposits in our sampling of large to superlarge mineral deposits (LSLDs) amount to at least 0.1 million tons of $\mathrm{Li}_{2} \mathrm{O}$ including extracted ores. The lower limit of average content for the hard ore deposits was fixed at $0.6 \% \mathrm{Li}_{2} \mathrm{O}$, which is the minimal level that makes such deposits economically interesting. The limit for hydro-mineral objects in salars was not fixed, because the deposits of a like nature are exploited even with much lower contents due to lower operating costs. The final selection includes 71 LSLDs from all over the world (Figure 1, Table 1). They have been distributed among supercontinent cycles in accordance with the earlier substantiated geochronological limits [Tkachev and Rundqvist, 2016a, 2016b. Their resources were arranged on the geological timescale divided into 50-m.y. bins to analize the 


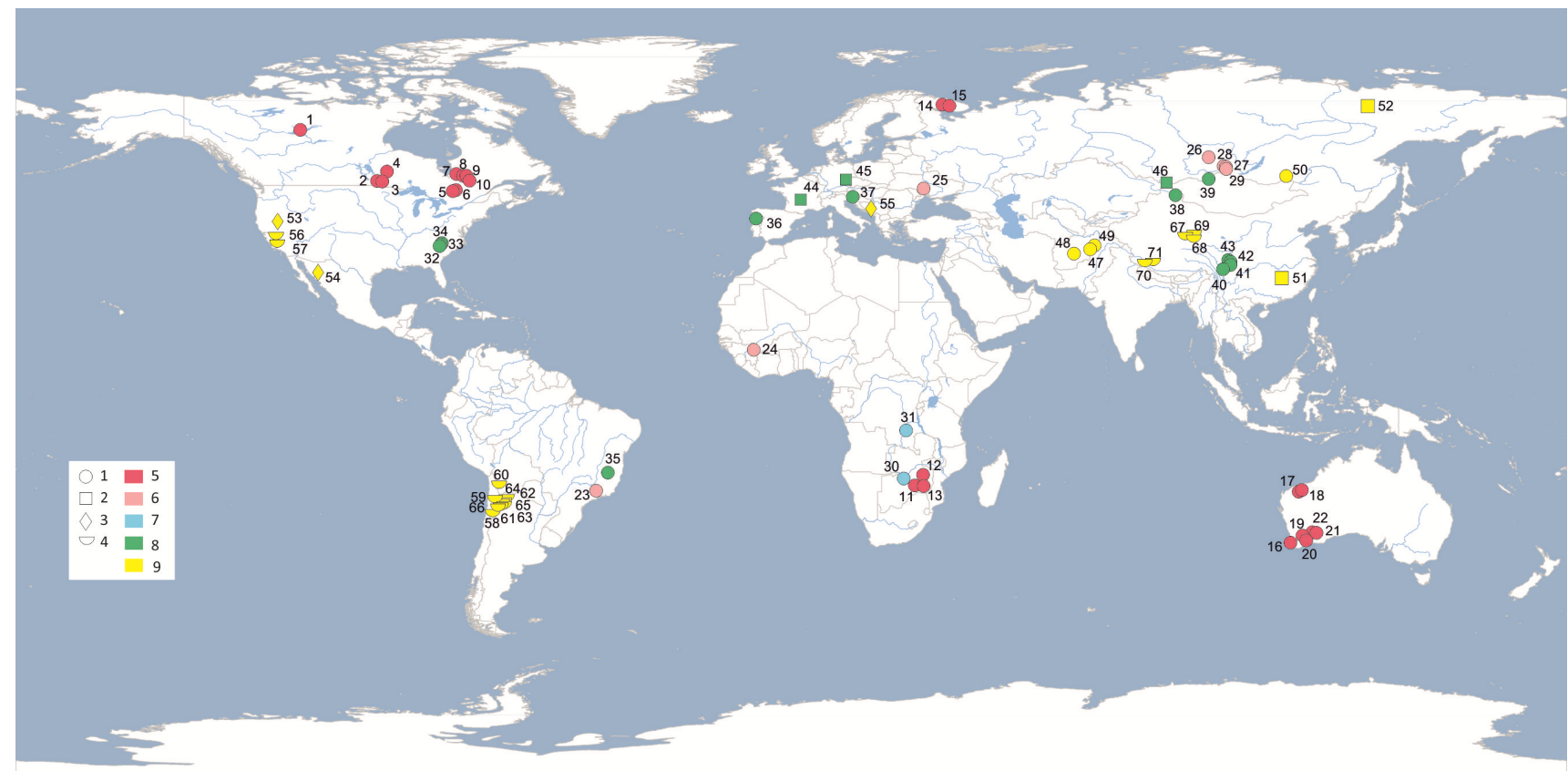

Figure 1. Distribution of lithium LSLDs included in the selection analyzed. 1-4 types of LSLDs: 1 - granite pegmatites, 2 - Li-F rare-metal granites, 3 - epithermal stratabound deposits, 4 - salar brines; 5-9 - supercontinent cycles: 5 - Kenoran, 6 - Columbian, 7 - Rodinian, 8 - Pangean, 9 - Amasian. Mineral deposits with their numbers on this map are listed in Table 1.

metallogeny of lithium through the geological time with a proper degree of detail.

\section{Comparison of Supercontinent Cycles in Terms of Lithium Metallogeny}

The calculated distribution of lithium LSLDs and their resources among supercontinent cycles is shown in Table 2. Most of the deposits, as well as the resources, are associated with the Amasian cycle, which is not yet completed. Furthermore, the deposits with the lowest average lithium grades also belong to this cycle. Even if salar brines (which obviously cannot be found in earlier periods) are eliminated from the selection, the same concentration patterns will persist. The oldest Kenoran cycle takes the second place in the number of both LSLDs and integral resources. The latter are characterized by the highest average lithium grade. If we analyze only hard ore LSLDs, this cycle takes the lead in most parameters (Table 2). The Rodinian cycle has the lowest number of LSLDs with the highest average amount of resources. The
Columbian cycle is characterized by both the lowest total amount of resources and the lowest average amount of resources per object.

For a more detailed analysis, the obtained information was subdivided in accordance with the types of LSLDs (Table 3), and the resources were arranged on the geological timescale divided into 50-m.y. bins (Figure 2). The results are very illustrative.

The Kenoran cycle includes only pegmatite deposits including the oldest known occurrences of lithium mineralization - spodumene, lepidolite, holmquistite, Li-muscovite, and elbaite. These occurrences are presented by the albite and albitespodumene rare-metal pegmatites in the Ancient Gneiss Complex of Swaziland and Barberton greenstone belt, Kaapvaal craton [Grew et al., 2018. Harris et al., 1995. Trumbull, 1993. Their ages vary from 2.99 to 3.08 Ga (Figure 2). However, the oldest occurrences were eliminated from the sampling because of low-grade ores and few resources. Economically viable pegmatite LSLDs evidently meeting the used quantity and quality requirements appeared only in the late Mesoarchean era. In our sampling list they are presented by the 
Table 1. Mineral Deposits Analyzed in the Study

\begin{tabular}{|rlrl}
\hline$\#$ & Name & Age, & Commodities in \\
& & $\mathrm{Ga}$ & decreasing order \\
& & & of importance \\
\hline 1 & Yellowknife- & & \\
& Beaulieu & 2.59 & $\mathrm{Li}$ \\
2 & Tanco & 2.64 & $\mathrm{Li}, \mathrm{Ta}, \mathrm{Cs}, \mathrm{Be}, \mathrm{Sn}$ \\
3 & Separation-Rapids & 2.64 & $\mathrm{Li}, \mathrm{Rb}, \mathrm{Ta}$ \\
4 & Pakeagama-Lake & 2.67 & $\mathrm{Li}, \mathrm{Ta}, \mathrm{Cs}, \mathrm{Rb}$ \\
5 & Authier & 2.65 & $\mathrm{Li}$ \\
6 & La Corn & 2.65 & $\mathrm{Li}$ \\
7 & James Bay & 2.62 & $\mathrm{Li}$ \\
8 & Rose & 2.62 & $\mathrm{Li}, \mathrm{Ta}, \mathrm{Rb}, \mathrm{Cs}, \mathrm{Be}$ \\
9 & Whabouchi & 2.58 & $\mathrm{Li}, \mathrm{Be}$ \\
10 & Moblan & 2.64 & $\mathrm{Li}$ \\
11 & Zulu & 2.61 & $\mathrm{Li}, \mathrm{Ta}$ \\
12 & Arcadia & 2.59 & $\mathrm{Li}, \mathrm{Ta}$ \\
13 & Bikita & 2.62 & $\mathrm{Li}, \mathrm{Cs}, \mathrm{Be}, \mathrm{Ta}, \mathrm{Sn}$ \\
14 & Polmostundra & 2.52 & $\mathrm{Li}, \mathrm{Ta}, \mathrm{Be}$ \\
15 & Kolmozero & 2.52 & $\mathrm{Li}, \mathrm{Ta}, \mathrm{Be}$ \\
16 & Greenbushes & 2.53 & $\mathrm{Li}, \mathrm{Ta}, \mathrm{Sn}, \mathrm{Nb}$ \\
17 & Wodgina & 2.83 & $\mathrm{Li}, \mathrm{Ta}, \mathrm{Sn}, \mathrm{Be}$ \\
18 & Pilgangoora & 2.88 & $\mathrm{Li}, \mathrm{Ta}, \mathrm{Sn}, \mathrm{Be}$ \\
19 & Earl Grey & 2.62 & $\mathrm{Li}$ \\
20 & Mount Cattlin & 2.62 & $\mathrm{Li}, \mathrm{Ta}, \mathrm{Be}, \mathrm{Cs}$ \\
21 & Mount Marion & 2.62 & $\mathrm{Li}$ \\
22 & Bald Hill & 2.62 & $\mathrm{Li}, \mathrm{Ta}, \mathrm{Sn}$ \\
23 & Volta Grande & 2.03 & $\mathrm{Ta}, \mathrm{Li}, \mathrm{Sn}$ \\
24 & Goulamina & 2.08 & $\mathrm{Li}$ \\
25 & Polokhovo & 2.03 & $\mathrm{Li}, \mathrm{Sn}, \mathrm{Ta}, \mathrm{Rb}, \mathrm{Be}$ \\
26 & Vishnyakovskee & 1.84 & $\mathrm{Ta}, \mathrm{Li}, \mathrm{Sn}, \mathrm{Be}, \mathrm{Rb}, \mathrm{Cs}$ \\
27 & Belorechenskoe & 1.83 & $\mathrm{Li}, \mathrm{Ta}, \mathrm{Sn}, \mathrm{Be}$ \\
28 & Goltsovoe & 1.83 & $\mathrm{Li}, \mathrm{Ta}, \mathrm{Cs}, \mathrm{Sn}, \mathrm{Be}$ \\
29 & Urikskoe & 1.83 & $\mathrm{Li}, \mathrm{Ta}, \mathrm{Sn}, \mathrm{Be}$ \\
30 & Kamativi & 1.04 & $\mathrm{Sn}, \mathrm{Li}, \mathrm{Ta}, \mathrm{Be}$ \\
31 & Manono-Kitotolo \\
32 & Kings Mountain & 0.95 & $\mathrm{Li}, \mathrm{Ta}, \mathrm{Sn}$ \\
33 & Hallman Beam & 0.36 & $\mathrm{Li}, \mathrm{Sn}, \mathrm{Ta}, \mathrm{Be}$ \\
34 & Lincolnton & 0.36 & $\mathrm{Li}, \mathrm{Sn}, \mathrm{Ta}, \mathrm{Ba}, \mathrm{Be}$ \\
35 & Cachoeira & $0.50 \mathrm{Li}, \mathrm{Ta}, \mathrm{Sn}$ \\
& &
\end{tabular}

Table 1. (continued)

\begin{tabular}{|c|c|c|}
\hline \# Name & $\begin{array}{l}\text { Age, } \\
\text { Ga }\end{array}$ & $\begin{array}{l}\text { Commodities in } \\
\text { decreasing order } \\
\text { of importance }\end{array}$ \\
\hline 36 Sepeda & 0.31 & $\mathrm{Li}, \mathrm{Sn}$ \\
\hline 37 Weinebene & 0.24 & $\mathrm{Li}$ \\
\hline 38 Keketuohai & 0.21 & $\mathrm{Li}, \mathrm{Be}, \mathrm{Ta}$ \\
\hline 39 Tastyg & 0.49 & $\mathrm{Li}, \mathrm{Ta}, \mathrm{Be}, \mathrm{Sn}, \mathrm{Nb}$ \\
\hline 40 Jiajika & 0.21 & $\mathrm{Li}, \mathrm{Be}, \mathrm{Ta}$ \\
\hline 41 Yelonggou & 0.20 & $\mathrm{Li}, \mathrm{Ta}, \mathrm{Be}, \mathrm{Sn}$ \\
\hline 42 Lijiagou & 0.20 & $\mathrm{Li}, \mathrm{Be}, \mathrm{Sn}, \mathrm{Ta}$ \\
\hline 43 Dangba & 0.20 & $\mathrm{Li}, \mathrm{Ta}$ \\
\hline 44 Echassieres & 0.33 & $\mathrm{Li}, \mathrm{Ta}, \mathrm{Sn}, \mathrm{Be}, \mathrm{W}$ \\
\hline 45 Cinovec & 0.32 & $\mathrm{Sn}, \mathrm{Li}, \mathrm{W}$ \\
\hline 46 Alakha & 0.20 & $\mathrm{Li}, \mathrm{Ta}$ \\
\hline 47 Taghawlor & 0.03 & $\mathrm{Li}, \mathrm{Ta}$ \\
\hline 48 Shamakat & 0.03 & $\mathrm{Li}$ \\
\hline 49 Parun & 0.03 & $\mathrm{Li}, \mathrm{Ta}, \mathrm{Be}$ \\
\hline 50 Zavitinskoe & 0.13 & $\mathrm{Li}, \mathrm{Ta}, \mathrm{Be}$ \\
\hline 51 Yichun & 0.16 & $\mathrm{Li}, \mathrm{Ta}, \mathrm{Rb}, \mathrm{Cs}$ \\
\hline 52 Kester & 0.14 & $\mathrm{Li}, \mathrm{Sn}, \mathrm{Rb}, \mathrm{Cs}$ \\
\hline 53 Kings Valley & 0.02 & $\mathrm{Li}, \mathrm{K}$ \\
\hline 54 La Ventana-El Sauz & 0.02 & $\mathrm{Li}, \mathrm{K}, \mathrm{Rb}, \mathrm{Cs}$ \\
\hline 55 Jadar & 0.02 & $\mathrm{Li}, \mathrm{B}$ \\
\hline 56 Silver Peak & recent & $\mathrm{Li}$ \\
\hline 57 Searles Lake & recent & $\mathrm{B}, \mathrm{Li}, \mathrm{W}$ \\
\hline 58 Salar de Maricunga & recent & $\mathrm{Li}, \mathrm{K}$ \\
\hline 59 Salar de Atacama & recent & $\mathrm{Li}, \mathrm{I}, \mathrm{K}, \mathrm{B}$ \\
\hline 60 Salar de Uyuni & recent & $\mathrm{Li}, \mathrm{Mg}, \mathrm{K}, \mathrm{B}$ \\
\hline 61 Salar del Hombre Muerto & recent & $\mathrm{Li}, \mathrm{B}, \mathrm{K}$ \\
\hline 62 Salar del Rincon & recent & $\mathrm{Li}, \mathrm{K}, \mathrm{Na}$ \\
\hline 63 Salar de Diabollos & recent & $\mathrm{Li}, \mathrm{K}$ \\
\hline 64 Salar de Olaroz & recent & $\mathrm{Li}, \mathrm{K}, \mathrm{B}$ \\
\hline 65 Salar de Pozuelos & recent & $\mathrm{Li}$ \\
\hline 66 Salar de Rio Grande & recent & $\mathrm{Li}$ \\
\hline 67 Yiliping-Taijinaier & recent & $\mathrm{Li}, \mathrm{B}$ \\
\hline 68 Qarhan & recent & $\mathrm{Li}, \mathrm{K}, \mathrm{B}$ \\
\hline 69 Dachaidan & recent & $\mathrm{Li}, \mathrm{K}, \mathrm{B}$ \\
\hline 70 Zabuye & recent & $\mathrm{Li}, \mathrm{K}, \mathrm{B}$ \\
\hline 71 Dangxiongcuo & recent & $\mathrm{Li}, \mathrm{B}, \mathrm{K}$ \\
\hline
\end{tabular}

Pilgangoora and Wodgina deposits, Pilbara craton (Figure 1).

The Neoarchean LSLDs are more numerous and wider distributed than the Mesoarchean ones. The largest number of the Neoarchean LSLDs (nine) has been discovered in granite-greenstone-schist belts of the Superior craton: Tanco, La Corne,
James Bay, etc. (Figure 1). They are also found in similar belts located at some other cratons: Slave (Yellowknife-Beaulieu deposit), Yilgarn (Greenbushes, Earl Grey, Mount Marion, etc.), Zimbabwe (Bikita, Arcadia, and Zulu), and Kola (Kolmozero and Polmostundra).

The mineralogy of lithium in pegmatite deposits 
Table 2. Distribution of Integrated Lithium Resources in LSLDs Through Supercontinent Cycles

\begin{tabular}{lcccccc}
\hline Supercontinental cycle $(\mathrm{Ga})$ & $N$ & $R$ & $R_{m}$ & $C$ & $X$ & $x$ \\
\hline Kenoran $(>2.25)$ & 22 & 17.22 & 0.78 & 1.42 & 21.3 & 35.2 \\
Columbian (1.35-2.25) & 7 & 2.44 & 0.35 & 1.05 & 3.0 & 5.0 \\
Rodinian (0.75-1.35) & 2 & 7.70 & 3.85 & 1.19 & 9.5 & 15.7 \\
Pangean (0.19-0.75) & 15 & 10.58 & 0.71 & 1.28 & 13.1 & 21.6 \\
Amasian (<0.19) & $25 / 9$ & $42.94 / 11.04$ & $1.72 / 1.23$ & $0.15 / 0.96$ & 53.1 & 22.5 \\
Total & $71 / 55$ & $80.89 / 48.99$ & $1.14 / 0.89$ & $0.69 / 1.25$ & 100.0 & 100.0
\end{tabular}

Note: a) indications of columns: $N$ - number of selected LSLDs, $R$ - total integrated resources (mined + reserves + resources, $10^{6}$ tons $\left.\mathrm{Li}_{2} \mathrm{O}\right), R_{m}$, mean quantity of integrated resources per $\mathrm{LSLD}\left(10^{6}\right.$ tons $\left.\mathrm{Li}_{2} \mathrm{O}\right), C-$ weighted mean grade of $\mathrm{Li}_{2} \mathrm{O}$ in ores $(\%), X$ - share of integrated resources of LSLDs referred to the given supercontinent cycle relative to the entire sampling $(\%), x$ - the same minus hydromineral resources (\%); b) template of data record for the Amasian and Total: $n / m$, where $n$ is the data for all LSLDs, $m$ is the same minus hydromineral LSLDs.

always has several phases regardless of the age. But in most cases only spodumene, resulting from either direct crystallization from melts or sub-solidus breakdown of primary magmatic petalite [London, 1984, is of interest for commercial extraction. The Kenoran LSLDs have some interesting examples of economically viable accumulations of other lithium minerals for which the technological production schemes were developed (separate concentrates) and in some cases even implemented. These minerals include: amblygonite (Tanco and Bikita), lepidolite (Bikita), petalite (Bikita, Zulu, and Arcadia), and eucryptite (Bikita). The development of the Separation Rapids project gives a rare example of a pegmatite lithium deposit with a technological process not involving the extraction of spodumene in a separate concentrate at all, but extraction of petalite and probably lepidolite [Aiken et al.,2016].

The Columbian cycle also has only pegmatite LSLDs (Table 3). They originated in two impulses. The objects in the fold belts of the Brazilian (Volta Grande), West African (Goulamina), and Ukrainian (Polokhovo) shields were formed in the Middle Paleoproterozoic (2.03-2.08 Ga). LSLDs of the East Sayan belt (Goltsovoe, Vishnyakovskoe, etc.) appeared in the Middle Paleoproterozoic (1.82-1.84 Ga) Figure 1 and Figure 2). It is interesting to note that at the Polokhovo deposit almost all lithium is concentrated in petalite. For the Vishnyakovskoe deposit, the production technology for petalite and eucryptite concentrates was developed in addition to spodumene [Linde et al., 2000. Only spodumene is of economic interest at the other LSLDs of the cycle.

Table 3. Distribution of Integrated Lithium Resources in LSLDs of Different Types Through Supercontinent Cycles

\begin{tabular}{|c|c|c|c|c|c|c|c|c|c|c|c|c|c|c|c|c|c|c|c|c|}
\hline \multirow{3}{*}{ Cycle } & \multicolumn{20}{|c|}{ Metallogenic types of lithium LSLD } \\
\hline & \multicolumn{5}{|c|}{ Pegmatites } & \multicolumn{5}{|c|}{ Li-F rare-metal granites } & \multicolumn{5}{|c|}{ Epithermal stratabound } & \multicolumn{5}{|c|}{ Salar brines } \\
\hline & $N$ & $R$ & $R_{m}$ & $C$ & $x^{\prime}$ & $N$ & $R$ & $R_{m}$ & $C$ & $X$ & $N$ & $R$ & $R_{m}$ & $C$ & $X$ & $N$ & $R$ & $R_{m}$ & $C$ & $X$ \\
\hline Ker & 22 & 17.22 & 0.78 & 1.42 & 100.0 & - & - & - & - & - & - & - & - & - & - & - & - & - & - & - \\
\hline Columbian & 7 & 2.44 & 0.35 & 1.05 & 100.0 & - & - & - & - & - & - & - & - & - & - & - & - & - & - & - \\
\hline Rodinian & 2 & 7.70 & 3.85 & 1.19 & 100.0 & - & - & - & - & - & - & - & - & - & - & - & - & - & - & - \\
\hline Pangean & 12 & 9.50 & 0.79 & 1.39 & 89.8 & 3 & 1.08 & 0.36 & 0.77 & 10.2 & - & - & - & - & - & - & - & - & - & - \\
\hline Amasian & 4 & 3.28 & 0.82 & 1.35 & 7.6 & 2 & 1.28 & 0.64 & 0.67 & 3.0 & 3 & 6.49 & 2.16 & 0.90 & 15.1 & 16 & 31.90 & 1.99 & 0.12 & 74.3 \\
\hline Total & 47 & 40.14 & 0.83 & 1.34 & 49.0 & 5 & 2.36 & 0.47 & 0.71 & 3.0 & 3 & 6.49 & 2.16 & 0.90 & 8.1 & 16 & 31.90 & 1.99 & 0.12 & 40.0 \\
\hline
\end{tabular}

Note: $x^{\prime}$ - share of integrated resources of LSLDs of given type referred to the given supercontinent cycle relative to the total resources of the cycle (\%); the other indications are the same as in Table 2. 


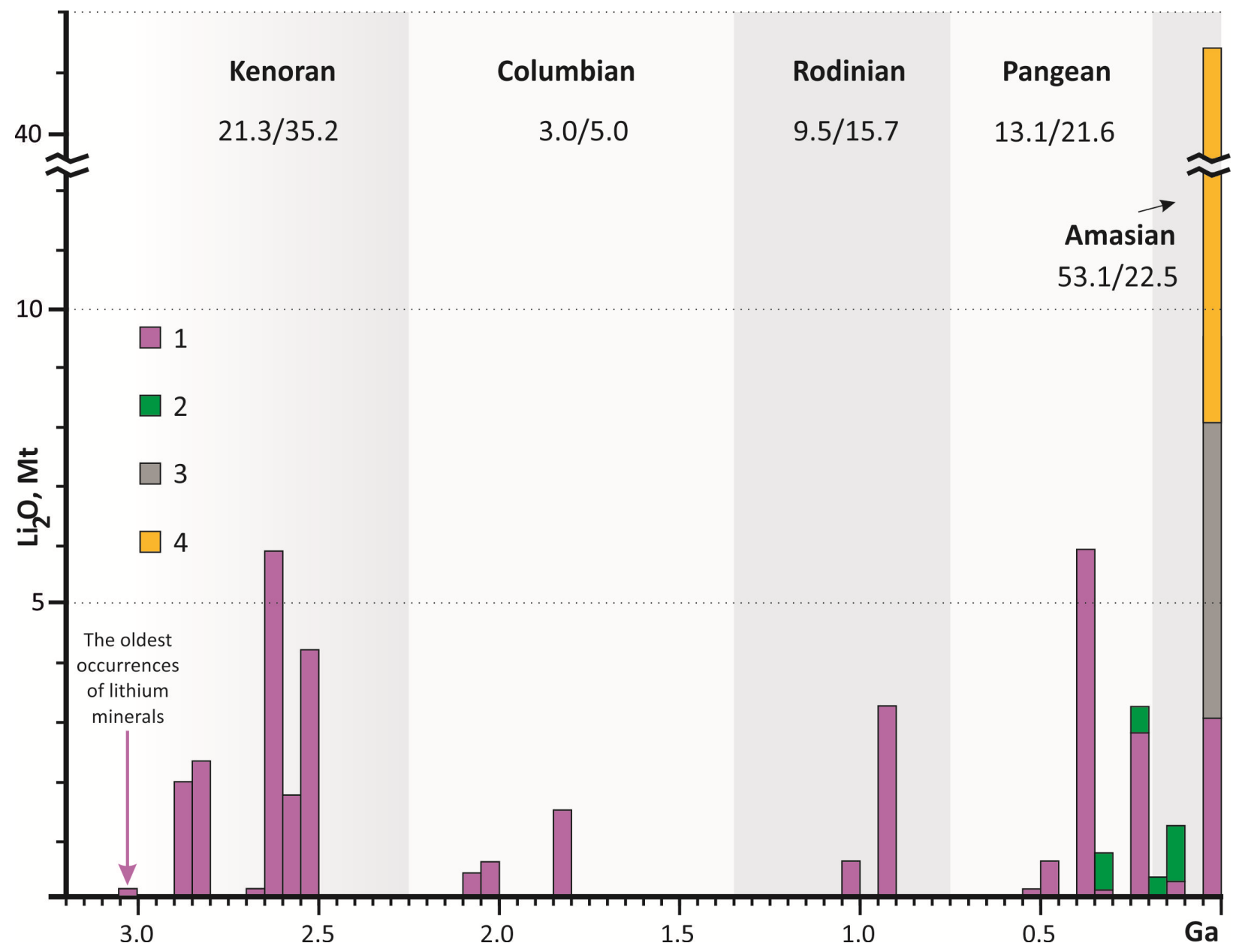

Figure 2. Distribution of lithium resources accumulated in LSLDs through geological time. A top number under a name of a supercontinent cycle shows a part (\%) of the cycle in the total integrated resources of the analyzed selection, and a bottom one - the same value minus the resources of lithium-bearing salar brines. Key for LSLD types: 1 granite pegmatites, 2 - Li-F rare-metal granites, 3 - epithermal stratabound deposits, and 4 - salar brines.

The Columbian cycle lags behind the Kenoran cycle in all comparatives and behind all other cycles in the total amount of resources. Along with that, it exceeds the Rodinian cycle in the number of LSLDs and the Amasian cycle in average $\mathrm{Li}_{2} \mathrm{O}$ grades (Table 2, Table 3).

The Rodinian cycle is similar to the Kenoran and Columbian ones in the uniformity of lithium LSLD types (Table 3, Figure 2). At the same time, it is behind all the cycles in the number of LSLDs: only two objects of this period have been established. Both are located in the Grenvillides of the southern Central Africa: Manono-Kitotolo in the Kibaran belt and Kamativi in the Dete-Kamativi crystalline massif reactivated in the latest Mesoproterozoic
(Figure 1). The Rodinian cycle significantly surpasses all the other cycles in the average amount of resources per object. This is mainly accounted for by the fact that the Rodinian sampling includes the Manono-Kitotolo lithium deposit. It is the second largest LSLD in the world [Dewaele et al., 2015. Mohr et al., 2012 and could even take the lead after the completion of exploration (Manono Project, https://avzminerals.com.au/manono-mine/, access 10 April 2018). Very low number of LSLDs corresponding to this cycle makes the average value of the current sampling hypersensitive to the data of the Manono-Kitotolo superlarge deposit.

Spodumene is of the main interest in the pegmatites of the Rodinian cycle, although it is pos- 
sible to extract lepidolite from some ore bodies at the Manono-Kitotolo deposit (Manono Project, https://avzminerals.com.au/manono-mine/, access 10 April 2018).

The number of objects representing the Pangean cycle is greater than that for the Columbian and Rodinian cycles. The Pangean cycle is behind the Kenoran one in all the compared parameters, but it is above the Columbian and Rodinian ones in total resources and in the average lithium grades in ores (Table 2).

The fundamental distinction of the Pangean cycle from all the earlier cycles is the appearance of Li-F rare-metal granites in the LSLDs sampling (Table 3, Figure 1 and Figure 2). This type of lithium deposits shows a remarkable similarity with rare-metal pegmatites. Both rare metal granites and pegmatites originate from intracrustal parental magmas and locate in orogenic belts in the postorogenic stage. Mineral and bulk chemical composition of the granites and pegmatites, including ore elements defining their metallogenic specialization, are similar too. However, inner zoning, textural features of minerals, and morphology of Li-F granite intrusions, as well as local geological settings of ore deposits, discriminates them from pegmatites. This gives the grounds to consider them to be separate types of rare-metal deposits [Bogatikov et al., 2010, Solodov, 1980: Tkachev, 2011.

Three Pangean lithium LSLDs in Li-F granites have been established: Echassieres in the French Massif Central, Cinovec in the Bohemian massif and Alakha in the Altay belt (Figure 1). In all of them lithium mineralogy has many phases, but the economic potential is defined by one specific mineral for each case: lepidolite in the first case, zinnwaldite in the second one, and spodumene in the third one. These deposits combined give a contribution equivalent to one tenth of the Pangean total resources.

The pegmatite LSLDs dominate in the total resources of the cycle (Table 3). The most significant resources are established in the Appalachian belt (Kings Mountain, etc.) and Songpan-Garzi belt (Jiajika, etc.) (Figure 1). Besides, they are located in the Aracuai belt (Cachoeira), Iberian belt (Sepeda), Altay belt (Keketuohai), Tuva-Mongol belt (Tastyg), and in the Paleozoic complexes of the Alpine belt (Weinebene). Only in Sepeda the main lithium-bearing mineral is petalite, while spodumene predominates in the other objects. In Keketuohai, lepidolite also makes an important contribution.

The Amasian cycle has some peculiarities that make it difficult to objectively compare it to the other supercontinent cycles. Firstly, it is far from the end, since the cycle has not yet passed through all the evolution stages of a new supercontinent creation. The major events are yet to come and will take place in the very distant future [Duarte et al., 2018. Secondly, nowadays the main part of lithium resources available for extraction is located in brines of salars. If their analogues existed during some other cycles (there are some chances), they would not retain due to their liquid phase state. In our sampling these present-day deposits contain roughly $40 \%$ of total resources and about $75 \%$ of resources in the Amasian cycle (Table 2, Table 3).

Some reviews of the world mineral resources give a higher percentage of brines in the world resources than the above mentioned one. Such variations are easy to explain. Firstly, we have used more recent estimations for some deposits of hard ores. Some of them were reassessed due to the significant growth in resources or even assessed for lithium for the first time in the last two or three years (Pakeagama Lake, James Bay, Earl Grey, Manono-Kitotolo, Cinovec, etc.). Secondly, the LSLD database resource estimations take into account a low extraction level from brines (about 50\%) at multistage natural evaporation. This is the technology used in the most of such deposits [Meshrama et al., 2014.

Almost all economically interesting salars are already under operation or in the development. They have accounted for $50-60 \%$ of the world lithium production since the beginning of the 21st century [Christmann et al., 2015, Evans, 2014. Meanwhile, there are only a few regions in the world where salars are located (Figure 1). They include the Altiplano-Puna plateau (Atacama, Uyuni, Hombre Muerto, etc.), Basin and Range province (Silver Peak and Searles Lake), Qaidam basin of Tibetan plateau (Dachaidan, Qinghai, and Yiliping-Taijinaier), and intermountain troughs of Lhasa (Zabuye and Dangxiongcuo). All these regions are geodynamically active areas with surfacedischarging mineralized ( $\mathrm{K}, \mathrm{Na}, \mathrm{Mg}, \mathrm{Li}, \mathrm{B}$ ) epithermal solutions and a strong arid climate, as well 
as with the tectonic-driven relief favorable for formation of drainless lakes [Romanyuk and Tkachev, 2010; Tkachev and Romanyuk, 2010.

Almost all operations on salars produce boron as a by-product in addition to lithium compounds. Boron is also extracted in the same regions from borate beds in older lacustrine evaporites. Some of those beds are located at the shorelines of Li-Bbearing saline lakes. The most famous example is the producing Tincalayu borate deposit of the Upper Miocene age located at the shore of the Hombre Muerto Salar containing brines used for both lithium and boron extraction.

Despite constant coexistence of lithium and boron in salar brines, evaporitic lithium minerals have not been found in borate beds anywhere in the world. This observation can be explained by extra-high solubility of lithium salts (haloids, carbonates, sulfates) that are only possible in such environments (Warren J. K., Lithium in saline geosystems: Lake brines and clays, Salty Matters, 2017, p. 1-13, http://www.saltworkconsultants.com/assets/29.lithium_saline.pdf, access April 10, 2018).

As far as the global geohistorical retrospective is considered, the earliest continental evaporates with borate ores, similar to the Cenozoic ones, are noted within the ca. 2.2-Ga volcanogenic-sedimentary complexes in the North China Craton [Peng and Palmer, 2002. No lithium mineralization is described there either. Nevertheless, the composition with modern analogues allows us to suppose that boron-lithium paragenesis in salars of geodynamically active continental areas could occur as early as in the Paleoproterozoic just after the Great Oxygenation Event (GOE). The GOE caused stable free oxygen availability in both the Earth atmosphere and uppermost hydrosphere no later than 2.3 Ma ago [Gumsley et al., 2017]. This, in turn, affected the sedimentary lithogenesis, especially, the composition of chemogenic rocks. The start of borate sedimentation in favorable environments was among these consequences. At the same time, strong direct evidences of the boron-lithium coexistence in ancient salar brines are still missing, and it cannot be claimed for sure that the pre-Cenozoic salars contained both boron and lithium, as the recent ones do.

Epithermal stratabound deposits are another type of lithium LSLDs, and they are unique to
Amasian cycle. They form the second largest sampling of the resource base in the cycle (Table 3 . Figure 2). This type is the most understudied due to the fact that it sparked the interest of lithium prospecting and mining companies, and therefore of scientists, later than the other types. For now, only three objects have been estimated. All of them were discovered in the active back-arc continental belts. The epithermal-type deposits are located in volcanogenic-sedimentary lacustrine sections of former lakes that appeared at the margins of volcanic calderas during the vanishing stage of magmatic activity.

The details of genetic model for this type of lithium deposits have been poorly studied. There is almost no doubt that such deposits have an epigenetic origin: lithium-bearing epithermal high-saline solutions metasomatically altered the beds of vitroclastic tuffs or borate-bearing silicate-carbonate sediments which were favorable in petrophysic and petrochemic aspects [Evans, 2014. Kesler et al., 2012. Depending on the replaced substrates, two subtypes of mineral deposits were formed: hectorite subtype (hectorite, lithium-bearing varieties of illite, kaolin, and/or montmorillonite) in the Basin and Range province (Kings Valley and La Ventana - El Sauz) and borosilicate-borate subtype (jadarite, colemanite, ulexite, and probertite) in the Jadar volcanogenicsedimentary depression in the Balkans (Figure 1. These objects are located in the same provinces with the world's largest epicontinental borate deposits. All these lithium and borate deposits are similar in their Miocene age and tend to gravitate to the centers of continental high-potassic volcanism. What is different between them is more distant localization of the borate deposits from the volcanic centers. Therefore, the hard ore industrial accumulations of both boron and lithium combined in the same ore bodies had not been known until the discovery of B-Li Jadar deposit in 2004. Such a unique juxtaposition of evaporitic sodic-calcic borates with a lithium borosilicate can be explained by the epigenetic model only (Warren J. K., Lithium in saline geosystems: Lake brines and clays, Salty Matters, 2017, p. 1-13, http://www.saltworkconsultants.com/assets/29.lithium_saline.pdf, access April 10, 2018).

Lithium pegmatite LSLDs in the Amasian cycle are established in two metallogenic belts (Figure 1) 
- Transbaikalian belt (Zavitinskoe) and Hindu Kush belt (Parun, Shamakat, Taghawlor). Spodumene is the main lithium mineral there. In the Amasian cycle, the resource share of this type is minimal (Table 3). This is partly related to wider diversity of lithium LSLDs in the cycle. The apparent incompleteness of the cycle is another important reason, because rare-metal pegmatites, including lithiumbearing ones, come into being in the end of a collapse phase development of the collision orogens [Tkachev, 2011]. Such orogens arise most actively at the culmination stage of a supercontinent cycle, when separated sialic continental blocks unite in a giant supercontinent [Rogers and Santosh, 2004]. For the future Amasian supercontinent, this most active phase of the collision belt formation is still far ahead [Duarte et al., 2018].

The explanation for the minimal number of lithium pegmatite LSLDs in the Rodinian cycle can be possibly found in the same area of geological factors as well. The fragmentation of the continental crust was minimal through the whole Rodinian cycle [Bradley, 2008. Therefore, the number of collision orogens that sutured the Rodinia supercontinent was also abnormally low [Condie, 2013]. Respectively, the probability of formation of pegmatite LSLDs was proportionately lower.

In the Amasian cycle the contribution of $\mathrm{Li}-\mathrm{F}$ granite into lithium resources is the smallest (Table 3). Although their Mesozoic and Cenozoic occurrences are numerous and widely distributed geographically [Kostitsyn, 2000], only two objects correspond to the qualitative limits for lithium deposits established in the study (Figure 2). Both were formed from the Late Jurassic to Early Cretaceous. The Yichun deposit in the South China belt is the current world-leader in lepidolite production. The Kester deposit in the Verkhoyansk belt is potentially the largest amblygonite source (with some lepidolite). It is well known as a former tin mine but only preliminarily estimated as a lithium object (Figure 1).

\section{Comparison of Quantitative Characteristics of LSLDs of Different Types}

The comparison of quantitative parameters between lithium pegmatite LSLDs shows that their vast majority falls in the relatively compact field of $\mathrm{Li}_{2} \mathrm{O}$ contents from 0.9 to 1.5 (Figure 3). Deviations from the limits of the range are rare.

It should be noted that no Kenoran objects lie in the range of $\mathrm{Li}_{2} \mathrm{O}$ less than $0.9 \%$, whereas all three values of $\mathrm{Li}_{2} \mathrm{O}$ above $2.0 \%$ belong to the Kenoran pegmatites: Bikita, Greenbushes, and Tanco. Against the background of all pegmatite LSLDs, these three stand out by the highest differentiation in internal structure of their thick (70-300 m) and long $(1.5-3 \mathrm{~km})$ bodies. They contain hundredsof-meters long and dozens-of-meters thick zones enriched in minerals (up to almost monomineral zones) that are interesting for the extraction of $\mathrm{Li}$, Ta, Cs, and Be [Martin, 1964, Partington et al., 1995. Stilling et al., 2006]. Among such zones, there are ones with extreme dominance of spodumene, petalite, or lepidolite. Each of these particular zones can be exploited by separate mine working systems.

In the cycles after the Kenoran, the pegmatite deposits with a similar complex of rare metals are established too, but there are no objects with similar contrast and large-scale mineral zones that could be mined separately over the years. Even if the clear zoning is present in younger deposits (for example, Keketuohai), such zones are less numerous and notably smaller in size. Therefore, it would be logical to assume that in the Archean there were specific conditions that formed a particularly favorable environment in some areas for the generation of pegmatites with contrasting mineral differentiation on a large scale. Presumably, one of such conditions is a more intensive heat flow in the Earth crust resulting from the higher average mantle temperature in the Archean [Labrosse and Jaupart, 2007]. Supported by the heat flow from the interior, a high-temperature and lowgradient thermal field could exist for a long time $\left(n \times 10^{6}\right.$ years $)$ in the abyssal zone of relaxing orogens where rare-metal pegmatites are commonly formed [Tkachev, 2011]. Such low-gradient thermal conditions are quite favorable for long-term differentiation of granite melts through fracture and cavity systems in country rocks. These successively opening voids promote the generation of the melt portions enriched in fluxing rare elements and volatiles in final chambers. These portions can crystallize as pegmatite bodies exceptionally enriched in some rare metals including lithium. 


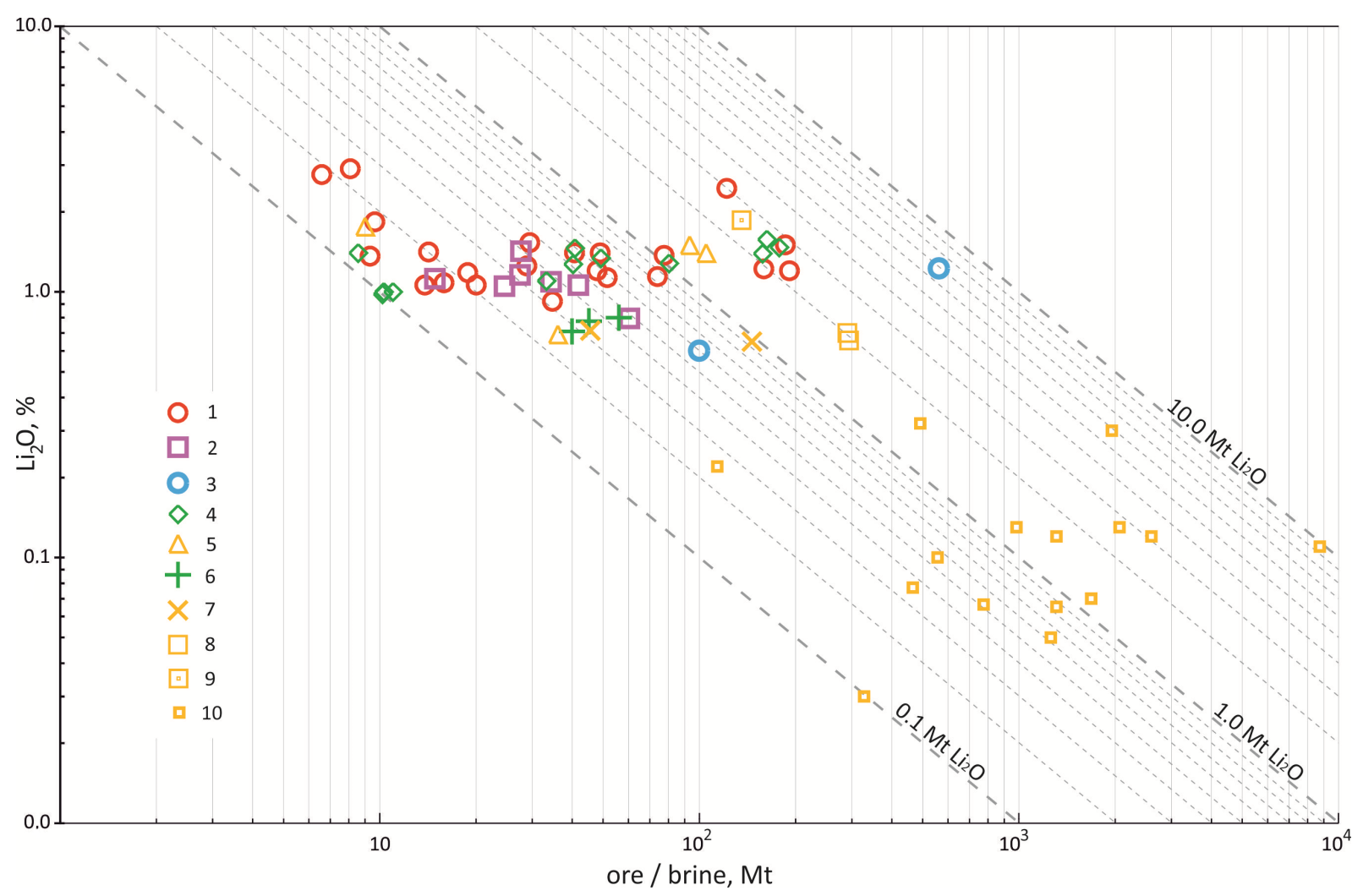

Figure 3. "Grade-tonnage" diagram of lithium LSLDs (logarithmic scale is used for both axes). Key for types and age of LSLDs: $1-5$ - pegmatites of various cycles: $1-$ Kenoran, 2 - Columbian, 3 - Rodinian, 4 - Pangean, 5 - Amasian; 6-7 - Li-F granites of two cycles: 6 - Pangean and 7 -Amasian; 8-9-Amasian epithermal stratabound deposits: 8 - hectorite and 9 - jadarite subtypes; 10 - Amasian salar brines.

Furthermore, the low-gradient conditions are the most suitable for the heterogeneous mode of mineral nucleation in pegmatites. This mode of nucleation is characterized by extremely low rates of mineral growth and highly probable generation of successive monomineral zones or almost monomineral ones [Swanson, 1977, Tkachev, 1994]. These are exclusively favorable conditions for spatial separation of elements and minerals in pegmatites, including ore-forming ones.

As a matter of fact, a number of lithium pegmatite LSLDs of the Kenoran cycle is almost equal to the total number of LSLDs of the same type in all the other cycles taken together (Table 3). This gives a substantial confirmation of the special favorability of the Archean orogens for productive pegmatite formation. We believe that the main reason for this lies in the fact that high- temperature low-gradient zones in the Archean orogens lived much longer than in the younger ones.

The LSLDs in Li-F granites known in the Pangean and Amasian cycles have the fewest number of variations of quantitative parameters among all types (Figure 3). Even Cinovec, the only object in low-phosphorous granites with the prevalent zinnwaldite in its ores, does not differ in ore quantity from the other LSLDs associated with highphosphorous granites. On the diagram, all the points belonging to the deposits related to $\mathrm{Li}-\mathrm{F}$ granites are close to the points of the pegmatite objects with poor ores and medium-sized resources.

In terms of the resource amount, the points of epithermal stratabound LSLDs are above the average values of the whole LSLDs list (Figure 3). The deposits of this type with different mineralogy are distinct in their lithium grades: two hectorite de- 
posits fall together with Li-F granites and the only jadarite object is located higher than most of the pegmatite ones.

Finally, lithium LSLDs in salars form a separate field shifted to the lower $\mathrm{Li}_{2} \mathrm{O}$ concentrations in comparison with the field of hard ores (Figure 3). Despite such low grades, the salars will remain the leading type for industrial lithium extraction in the near future. Relatively low costs of technologies being used for lithium extraction support this trend [Christmann et al., 2015]. Meanwhile, mining and exploration companies are quite active in resource evaluation and exploitation of a growing number of LSLDs with hard lithium ores. This fact together with the growing worldwide consumption of lithium [Christmann et al., 2015, Evans, 2014, Mohr et al., 2012 suggests that the objects with hard ores have not lost their economic importance and can even increase it further. Therefore, further development of lithium metallogeny studies, including global geohistorical researches primed by this work, must be requisite for all types of lithium deposits in the foreseeable future.

\section{Conclusions}

The analysis of the global sampling of lithium LSLDs, containing almost all the established commercially important or potentially interesting lithium resources, has shown that these objects were formed at various geological periods from the Late Mesoarchean to the Holocene. Their distribution over geological time is pronouncedly discrete and intermittent.

Successive supercontinent cycles have defined the most important features of the Earth crust geotectonic evolution over the last three billion years. Among other things, the cycles vary in their specific characteristics of lithium metallogeny. In the Kenoran, Columbian, and Rodinian cycles, exclusively pegmatite lithium deposits were generated. Lithium potential of the Pangean cycle is also mainly formed by pegmatites, except for the small part of resources related to Li-F rare-metal granites. The uncompleted Amasian cycle is the most diverse in the types of lithium LSLDs. Pegmatites and $\mathrm{Li}-\mathrm{F}$ granites together account for only one tenth of the cycle's resources, epithermal stratabound objects amount to one-and-a-half times more, and salars constitute three quarters.
Pegmatite objects dominate among the hard ore lithium LSLDs both in quantity and in geographical distribution, being the only recurrent type in the Earth's geological history. The Kenoran cycle stands out with the maximum number of pegmatite LSLDs, their largest total resources, and the highest lithium grades. It means that conditions in that epoch were extremely favorable for the formation of large lithium-bearing pegmatite deposits. The higher heat flow through the Earth crust in the Archean orogens could support the prolonging existence of high-temperature low-gradient thermal fields which are favorable for pegmatite formation.

The salars, having significant shares in lithium resources and extraction, and epithermal stratabound LSLDs, being potentially important, are both observed for the Amasian cycle only. Theoretically, the lithium-bearing salars could exist in all geological eras since the Paleoproterozoic, but there is no direct evidence of their existence beyond the Miocene.

Acknowledgments. This study is supported by proj. no. 0140-2018-0003 of state studies at the Vernadsky State Geological Museum, RAS (creation of database and GIS) and project no. 0140-2018-0004 of the Program no. 48 of fundamental scientific studies at the Presidium RAS (data analysis and synthesis). The study is conducted at the Vernadsky State Geological Museum, Russian Academy of Sciences.

\section{References}

Aiken, S. R., R. Gowans, K. E. Hawton (2016), NI 43-101 Technical report on the preliminary economic assessment of lithium hydroxide production Separation Rapids Lithium Project, Kenora, Ontario, 278 pp. Micon International Ltd., Toronto.

Bogatikov, O. A., V. I. Kovalenko, E. V. Sharkov (2010), Magmatism, tectonics, and geodynamics of the Earth: spatiotemporal relationships, 606 pp. Nauka, Moscow. (in Russian)

Bradley, D. C. (2008), Passive margins through earth history, Earth-Science Reviews, 91, 1-26. Crossref

Christmann, P., E. Gloaguen, J.-F. Labbé, et al. (2015), Global Lithium Resources and Sustainability Issues, Chapter 1, Lithium Process Chemistry: Resources, Extraction, Batteries and Recycling, A. Chagnes \& J. Światowska (Eds.), 1-40 pp. Elsevier, Amsterdam.

Condie, K. C. (2013), Preservation and recycling 
of crust during accretionary and collisional phases of Proterozoic orogens: a bumpy road from Nuna to Rodinia, Geosciences, 3, 240-261. Crossref

Dewaele, S., N. Hulsbosch, Y. Cryns, et al. (2015), Geological setting and timing of the world-class Sn, $\mathrm{Nb}-\mathrm{Ta}$ and $\mathrm{Li}$ mineralization of Manono-Kitotolo (Katanga, Democratic Republic of Congo), Ore Geology Reviews, 72, 373-390. Crossref

Duarte, J. C., W. P. Schellart, F. M. Rosas (2018), The future of Earth's oceans: consequences of subduction initiation in the Atlantic and implications for supercontinent formation, Geological Magazine, 155, 45-58. Crossref

Evans, K. R. (2014), Lithium, Chapter 10, Critical Metals Handbook. Hoboken, Gunn G. (ed.), 230-260 pp. Wiley-Blackwell, New Jersey, USA.

Grew, E. S., F. Bosi, M. E. Gunter, et al. (2018), Fluor-elbaite, lepidolite and $\mathrm{Ta}-\mathrm{Nb}$ oxides from a pegmatite of the $3000 \mathrm{Ma}$ Sinceni pluton, Swaziland: Evidence for lithium-cesium-tantalum (LCT) pegmatites in the Mesoarchean, European J. Mineralogy, 30, No. 2, 25-39. Crossref

Gumsley, A. P., K. R. Chamberlain, W. Bleeker, et al. (2017), Timing and tempo of the Great Oxidation Event, PNAS, 114, No. 8, 1811-1816. Crossref

Harris, P. D., L. J. Robb, M. J. Tomkinson (1995), The nature and structural setting of rare-element pegmatites along the nothern flank of the Barberton greenstone belt, South Africa, South Afr. J. Geology, 98, No. 1, 82-94.

Kesler, S. E., P. W. Gruber, P. A. Medina, et al. (2012), Global lithium resources: relative importance of pegmatite, brine and other deposits, Ore Geology Reviews, 48, 55-69. Crossref

Kostitsyn, Yu. A. (2000), Sources of peraluminous rare-metal granites: a review of $\mathrm{Rb}-\mathrm{Sr}$ and $\mathrm{Sm}-\mathrm{Nd}$ isotopic data, Ore-Bearing Granites of Russia and Adjusting Countries, A. A. Kremenetskiy et al. (Eds.), p. 143-156, IMGRE, Moscow.

Labrosse, S., C. Jaupart (2007), Thermal evolution of the Earth: secular changes and fluctuations of plate characteristics, Earth Planet. Sci. Letters, 260, 465-481. Crossref

Li, J., T. Zou, X. Liu, et al. (2015), The metallogenetic regularities of lithium deposits in China, Acta Geologica Sinica, 89, No. 2, 652-670. Crossref

Linde, T. P., O. D. Stavrov, N. A. Yushko, et al. (2000), Lithium in Russia: state and perspectives for mining and further growth of the resource base, Mineral'noe syr'yo. Seriya Geologo-Economicheskaya, No. 6, 116. (in Russian)

London, D. (1984), Experimental phase equilibria in the system $\mathrm{LiAlSiO}_{4}-\mathrm{SiO}_{2}-\mathrm{H}_{2} \mathrm{O}$ : A petrogenetic grid for lithium-rich pegmatites, Amer. Mineralogist, 69, 995-1005.

Martin, Y. J. (1964), The Bikita tifield, Southern Rodesia Geological Survey Bulletin, 58, 114-143.

McCauley, A., D. C. Bradley (2014), The global age distribution of granitic pegmatites, Canadian Mineralogist, 52, 183-190. Crossref

Meshrama, P., B. D. Pandey, T. R. Mankhand (2014), Extraction of lithium from primary and secondary sources by pre-treatment, leaching and separation: A comprehensive review, Hydrometallurgy, 150, 192208. Crossref

Mohr, S. H., G. M. Mudd, D. Giurco (2012), Lithium resources and production: critical assessment and global projections, Minerals, 2, 65-84. Crossref

Partington, G. A., N. J. McNaughton, I. S. Williams (1995), A review of the geology, mineralization and geochronology of the Greenbushes pegmatite, Western Australia, Econ. Geology, 90, 616-635. Crossref

Peng, Q. M., M. R. Palmer (2002), The Paleoproterozoic $\mathrm{Mg}$ and $\mathrm{Mg}-\mathrm{Fe}$ borate deposits of Liaoning and Jilin provinces, northeast China, Econ. Geology, 97, 93-108. Crossref

Rogers, J. J. W., M. Santosh (2004), Continents and Supercontinents, 304 pp. Oxford University Press, Oxford.

Romanyuk, T. V., A. V. Tkachev (2010), Geodynamic Scenario of Forming of the Miocene-Quartern. World-Class Boron-Lithium-Bearing Provinces, 304 pp. IFZ RAS and GGM RAS, "Svetoch-plyus", Moscow. (in Russian)

Rundqvist, D. V., A. V. Tkachev, S. V. Cherkasov, et al. (2004), Database and metallogenic map of large and superlarge world deposits: principles of compilation and preliminary analysis of results, Large and superlarge ore deposits: Regularities in allocation and conditions of formation, p. 391-422, IGEM RAN, Moscow. (in Russian)

Rundqvist, D. V., A. V. Tkachev, S. V. Cherkasov, et al. (2006), Large and superlarge ore deposits. V. 1. Global regularities in localization, 390 pp. IGEM RAN, Moscow. (in Russian)

Solodov, N. A. (1980), Acid rare-metal granites, Mineral Deposits of Lithophile Rare Elements, p. 62-82, Nedra, Moscow. (in Russian)

Stilling, A., P. Cerny, P. J. Vanstone (2006), The Tanco pegmatite at Bernic Lake, Manitoba. XVI. Zonal and bulk compositions and the petrogenetic significance, Canadian Mineralogist, 44, 599-623. Crossref

Swanson, S. E. (1977), Relation of nucleation and crystal-growth to the development of granitic textures, American Mineralogist, 62, 966-978.

Tkachev, A. V. (2011), Evolution of metallogeny of granitic pegmatites associated with orogens throughout geological time, Granite-Related Ore Systems, A. N. Sial et al. (Eds.), Special Publications, 350, p. 7-23, Geological Society, London.

Tkachev, A. V., T. V. Romanyuk (2010), World's largest Miocene-Quoternary boron-lithium ore provinces. Paper 3. Geodynamic scenario of origin, Bull. MOIP, Seriya Geologicheskaya, 85, No. 1, 27-47. (in Russian) 
Tkachev, A. V., D. V. Rundqvist (2016a), Global trends in the evolution of metallogenic processes as a reflection of supercontinent cyclicity, Geology of Ore Deposits, 58, No. 4, 263-283. Crossref

Tkachev, A. V., D. V. Rundqvist (2016b), Influence of supercontinent cyclicity on global metallogenic processes: Main tendencies, Doklady Earth Sciences, 469, No. 2, 797-801. Crossref

Tkachev, A. V. (1994), Origin of the pegmatite zoning, Otechestvennaya Geologiya, No. 7, 52-58. (in Russian)

Tkachev, A. V., S. V. Bulov, D. V. Rundqvist, et al.
(2015), WEB-GIS "World's largest mineral deposits", Geoinformatika, No. 1, 47-59. (in Russian)

Trumbull, R. B. (1993), A petrological and Rb/Sr isotopic study of an early Archean fertile granitepegmatite system: the Sinceni pluton in Swaziland, Precambrian Res., 61, 89-116. Crossref

D. V. Rundqvist, A. V. Tkachev, and N. A. Vishnevskaya, Vernadsky State Geological Museum, Mokhovaya St. 11, bldg. 11, 125009 Moscow, Russia. (a.tkachev@sgm.ru; dvr@sgm.ru; 200962@mail.ru) 